\title{
A THIOLATO-BRIDGED OCTANUCLEAR COPPER(I,II) MIXED- VALENCE COMPLEX WITH N,N,S-TRIDENTATE LIGAND ${ }^{\S}$
}

\author{
Takanori Kotera, Tsukasa Sugimoto, and Masahiro Mikuriya* \\ Department of Chemistry and Open Research Center for Coordination Molecule-Based Devices, \\ School of Sciecne and Technology, Kwansei Gakuin University, Sanda, Hyogo 669-1337, Japan \\ *junpei@ksc.kwansei.ac.jp, TEL +81-79-565-8365, FAX+81-79-565-9077
}

\begin{abstract}
Thiolato-bridged complex $\left[\mathrm{Cu}_{4}^{\mathrm{I}} \mathrm{Cu}_{4}^{\mathrm{II}}(\text { peampt })_{4} \mathrm{Cl}_{8}\right] \cdot 2 \mathrm{H}_{2} \mathrm{O} \quad$ (Hpeampt $=1$-(2-pyridylethyl)amino) methylpropane-2-thiol) has been synthesized and characterized by the elemental analysis, IR and UV-vis spectroscopies and magnetic susceptibility measurement. The X-ray crystal structure analysis of this complex shows a localized mixed-valence octanuclear cage structure made up of four trigonal-bipyramidal $\mathrm{Cu}^{\mathrm{II}} \mathrm{N}_{2} \mathrm{SCl}_{2}$, two trigonal $\mathrm{Cu}_{2} \mathrm{~S}$ Cl, and two tetrahedral $\mathrm{Cu}^{\mathrm{I}} \mathrm{S}_{2} \mathrm{Cl}_{2}$ coordination sites. Temperature dependence of magnetic susceptibility $(4.5-$ $300 \mathrm{~K}$ ) shows that a fairly strong antiferromagnetic interaction is operating between the four $\mathrm{Cu}^{\mathrm{II}}$ ions.
\end{abstract}

Keywords: thiolato-bridged complexes; mixed-valence complexes; copper complexes; octanuclear complexes.

\section{INTRODUCTION}

Thiolato-bridged metal complexes with organic thiolic ligands have attracted much attention during the several decades because of their utilities as model complexes in relation to ubiquitous metal-cysteine centers of biologically important metal enzymes [1-3]. For example, thiolato-bridged copper species have been focused from a view of model compounds for nitrous oxide reductase and cytochrome c oxidase and these sites are interesting mixed-valent copper cluster with the spin-delocalized state [2]. However, isolation of thiolato-bridged metal complexes was generally hampered by the presence of undefined and undesired byproducts caused by electron-rich thiolato sulfur having a great affinity for various metal ions. Formation of discrete thiolato-bridged metal complexes could be expected to be feasible by the use of tridentate chelate ligands which have N,N,S-donor set by virtue of the chelating effect. Thus, we synthesized thiolic ligands such as 2-[(2-aminoethyl)amino]ethanethiol (Haeaet), 2-[(3-aminopropyl)amino]ethanethiol (Hapaet), 2-[(2-pyridylmethyl)amino]ethanethiol (Hpmaet), and 2-\{[2-(2-pyridyl)ethyl]amino\}ethanethiol (Hpeaet) and initiated a systematic study on thiolato-bridged metal complexes with these chelate ligands.<smiles>CC(C)(S)CNCCCN</smiles>

Hapampt<smiles>CC(C)(S)CNCCc1ccccn1</smiles>

Hpeampt

Scheme 1. N,N,S-tridentate thiolic ligands.

We isolated dinuclear nickel(II) complexes [4] and unique tetranuclear palladium(II) complexes [5] by reactions with nickel(II) and palladium(II) salts, repectively. In the case of zinc(II), linear and cyclic trinuclear and chain polynuclear complexes were obtained by these ligands [6]. Linear trinuclear structure consisting of octahedral-tetrahedral-octahedral coordination environments seems to be most favorable pattern in our systems and we isolated such species for the cases of $\mathrm{Zn}^{\mathrm{II}}, \mathrm{Cd}^{\mathrm{II}}, \mathrm{Mn}^{\mathrm{II}}, \mathrm{Fe}^{\mathrm{II}}, \mathrm{Co}^{\mathrm{II}}$, and $\mathrm{Ni}^{\mathrm{II}}$ [7-11]. We explored a facile synthetic method of trinuclear heterometal complexes by using one-pot reaction of Hapaet [11]. After getting these experiences, we tried to make copper systems of our thiolic ligands and obtained a polymeric compound of apaet ${ }^{-}$which could not be crystallized [12]. By the use of a similar NNS-chelating ligand containing methyl groups at the $\beta$-position, 1 -[(3-aminopropyl)amino]-2-methylpropane2-thiol (Hapampt), we could successfully isolated a hexanuclear mixed-valence complex with unique $\mathrm{Cu}_{3}^{\mathrm{I}} \mathrm{Cu}_{3}^{\mathrm{II}} \mathrm{cluster}$ in copper systems $[12,13]$. This may be ascribed to the presence of the methyl groups of the thiolic ligand to stabilize the mixed-valence state. We can expect formation of different type of copper complexes, if we introduce pyridyl group to this promising methyl-group-attached thiolic ligand, because it is known that pyridyl group is softer than the amino group. In this study, we synthesized a new thiolic ligand, 1-[(2-pyridylethyl)amino]methylpropane-2-thiol (Hpeampt) and examined the reactions with copper(II) ion in the hope of attaining to make mixed-valence species.

\footnotetext{
§ Material presented at the XV-th Conference "Physical Methods in Coordination and Supramolecular Chemistry", September 27 - October 1, 2006, Chişinău, Moldova.
} 


\section{RESULTS AND DISCUSSION}

In the case of the reaction of Hapampt ligand with copper(II) ion, a mixed-valent species, $\left[\mathrm{Cu}_{3}^{\mathrm{I}} \mathrm{Cu}_{3}^{\mathrm{II}}(\text { apampt })_{3} \mathrm{Cl}_{6}\right] \cdot 2 \mathrm{H}_{2} \mathrm{O}(\mathbf{1})$, was formed. The X-ray crystal structure analysis shows a hexanuclear cage structure, where each apampt ligand is bonded to one copper(II) ion to form two adjacent chelates with six- and fivemembered rings and each thiolato-sulfur is further bound to one copper(I) ion [12].

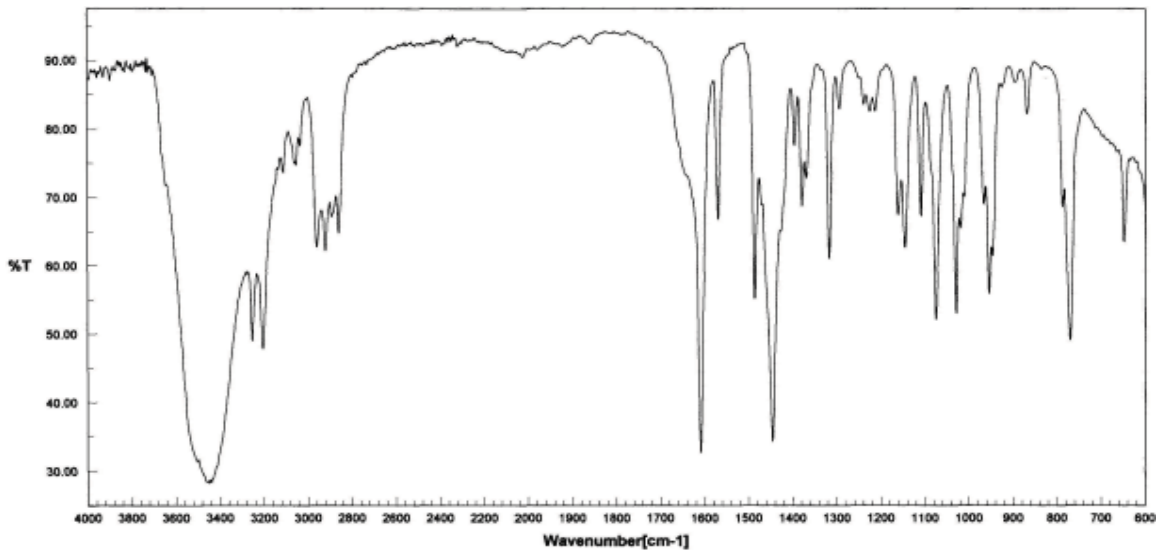

Fig. 1. Infrared spectra of $\left[\mathrm{Cu}_{4}^{\mathrm{I}} \mathrm{Cu}_{4}^{\mathrm{II}}(\text { peampt })_{4} \mathrm{Cl}_{8}\right] \cdot 2 \mathrm{H}_{2} \mathrm{O}(2)$.

The localized mixed-valence structure was also supported by the electronic spectra and the magnetic susceptibility data. From the structural similarity, it can be considered that the peampt ligand is capable of forming two adjacent six- and five-membered chelate rings like the apampt ligand. Therefore it was expected to obtain similar mixed-valent complexes to the hexanuclear cluster $\mathbf{1}$, although we can expect something different feature for product from reaction of the present thiolic ligand with copper(II) ion. Reaction of Hpeampt with copper(II) chloride dihydrate in methanol resulted in deprotonation of the thiolic ligand and gave black crystals of thiolato complex (2).

Crystallographic data for $\left[\mathrm{Cu}_{4}^{\mathrm{I}} \mathrm{Cu}_{4}{ }_{4}(\mathrm{peampt}){ }_{4} \mathrm{Cl}_{8}\right] \cdot 2 \mathrm{H}_{2} \mathrm{O}(2)$

Table 1

\begin{tabular}{|c|c|}
\hline & {$\left[\mathrm{Cu}_{4}^{\mathrm{I}} \mathrm{Cu}_{4}^{\mathrm{II}}(\mathrm{peampt})_{4} \mathrm{Cl}_{8}\right] \cdot 2 \mathrm{H}_{2} \mathrm{O}(2)$.} \\
\hline Empirical formula & $\mathrm{C}_{44} \mathrm{H}_{72} \mathrm{Cl}_{8} \mathrm{Cu}_{8} \mathrm{~N}_{8} \mathrm{O}_{2} \mathrm{~S}_{4}$ \\
\hline Formula weight & 1665.35 \\
\hline Temperature / K & 293 \\
\hline Crystal dimensions /mm & $0.1 \times 0.1 \times 0.05$ \\
\hline Crystal system & monoclinic \\
\hline Space group & $P 2, / \mathrm{c}($ No. 12$)$ \\
\hline$a / \AA$ & $12.829(11)$ \\
\hline$b / \AA$ & $24.24(2)$ \\
\hline$c / \AA$ & $12.494(11)$ \\
\hline$\alpha /{ }^{\circ}$ & 90 \\
\hline$\beta /{ }^{\circ}$ & $116.952(17)$ \\
\hline$\gamma / o$ & 90 \\
\hline$V / \AA^{3}$ & $3464(5)$ \\
\hline$Z$ & 2 \\
\hline$d_{\text {calcd. }} / \mathrm{gcm}^{-3}$ & 1.597 \\
\hline$\mu / \mathrm{mm}^{-1}$ & 2.873 \\
\hline Diffractometer & Bruker SMART APEX CCD \\
\hline No. of reflection & 11909 \\
\hline No. of observation & 3633 \\
\hline Refl./Parameter ratio & 10.7 \\
\hline$R 1, \mathrm{w} R 2[I>2 \sigma(I)]^{[\mathrm{a}]}$ & $0.1291,0.3039$ \\
\hline Goodness-of-fit on $F^{2}$ & 1.282 \\
\hline
\end{tabular}

In the infrared spectrum of $\mathbf{2}$, the absorption bands due to the peampt ligand appear as a set of absorption bands in a similar frequency region to that of the free thiol with lacking the $v(\mathrm{SH})$ band as shown in Fig. 1. The presence of $\mathrm{H}_{2} \mathrm{O}$ is suggested from the broad band around $3449 \mathrm{~cm}^{-1}$ attributable to the $v(\mathrm{OH})$ band of the crystal water molecules. 
Unfortunately, all of the crystals were twinned and we failed to obtain a satisfactory quality of crystallographic data for this complex, despite of many attempt to get good quality of single-crystals, and therefore a more detailed analysis of the structure of 2 could not be performed. However, we can find that the preliminary X-ray crystal structure reveals an octanuclear structure with formulation of $\left[\mathrm{Cu}_{4}^{\mathrm{I}} \mathrm{Cu}_{4}^{\mathrm{II}}(\text { peampt })_{4} \mathrm{Cl}_{8}\right] \cdot 2 \mathrm{H}_{2} \mathrm{O}$ that is distinctly different from 1 . The elemental analysis and the IR data also support this formulation. Crystal data and details concerning data collection are given in Tab. 1. An ORTEP drawing of $\mathbf{2}$ with atom-labeling scheme is shown in Fig. 2.

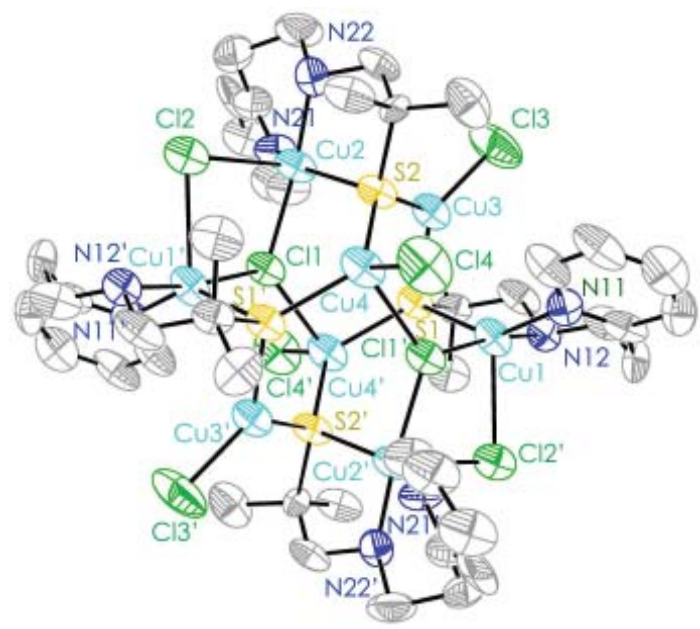

Fig. 2. ORTEP drawing of the structure of $\left[\mathrm{Cu}_{4}^{\mathrm{I}} \mathrm{Cu}_{4}^{\mathrm{II}}\right.$ (peampt) $\left.{ }_{4} \mathrm{Cl}_{8}\right] \cdot 2 \mathrm{H}_{2} \mathrm{O}(2)$ showing the $50 \%$ probability thermal ellipsoids and atom labeling scheme. Water molecules are omitted for clarity.

Selected bond distances and angles are listed in Table 2. The octanuclear molecule has a crystallograophically inversion center. The $\mathrm{Cu} 1$ (Cu1') atom is coordinated to the pyridyl-nitrogen N11 (N11'), amino-nitrogen N12 (N12'), and thiolato-sulfur $\mathrm{S} 1$ (S1') atoms of peampt in a meridional form, forming two adjacent six- and five-membered chelate rings. The $\mathrm{Cu} 2\left(\mathrm{Cu} 2^{\prime}\right)$ atom is also coordinated to the pyridyl N21 (N21'), amino N22 (N22'), and thiolato S2 (S2') of the thiolic ligand in a similar mode.

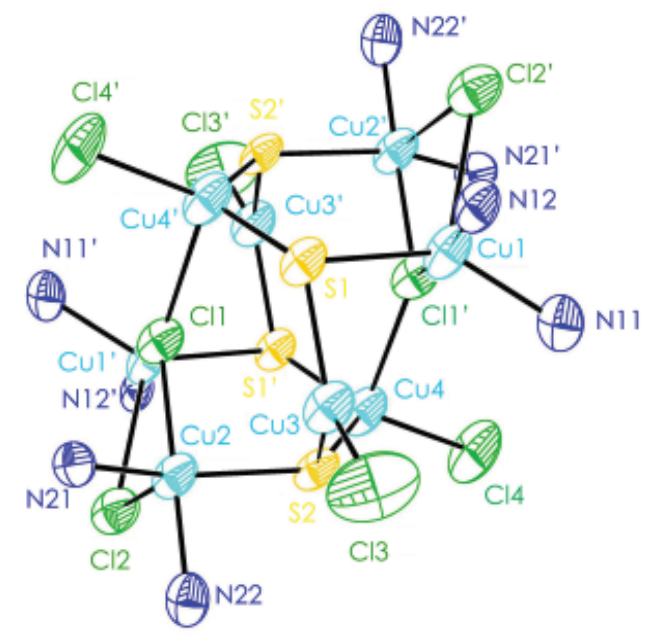

Fig. 3. Core structure of of $\left[\mathrm{Cu}_{4}^{\mathrm{I}} \mathrm{Cu}_{4}{ }_{4}\right.$ (peampt) $\left.{ }_{4} \mathrm{Cl}_{8}\right] \cdot 2 \mathrm{H}_{2} \mathrm{O}(2)$.

The $\mathrm{Cu} 3$ (Cu3') atom is coordinated to the thiolato S1 and S2 (S1' and S2') atoms to connect the Cu1(peampt) and $\mathrm{Cu} 2$ (peampt) (the $\mathrm{Cu} 1^{\prime}\left(\right.$ peampt)' and $\mathrm{Cu} 2^{\prime}\left(\right.$ peampt)') moieties. Similarly, the $\mathrm{Cu} 4\left(\mathrm{Cu} 4{ }^{\prime}\right)$ atom is coordinated to the thiolato S2 and S1' (S2' and S1) atoms to connect the $\mathrm{Cu} 2$ (peampt) and Cu1'(peampt)' (the Cu2'(peampt)' and $\mathrm{Cu} 1$ (peampt)) moieties. The octanuclear core is shown in Fig. 3.

The octanuclear copper core is made up of four trigonal-bipyramidal $\mathrm{Cu}^{\mathrm{II}} \mathrm{N}_{2} \mathrm{SCl}_{2}$, two trigonal $\mathrm{Cu} \mathrm{S}_{2} \mathrm{Cl}$, and two tetrahedral $\mathrm{Cu}_{2} \mathrm{~S}_{2} \mathrm{Cl}_{2}$ moieties and has adjacent six-membered rings [-Cu-S-Cu-S-Cu-Cl-] containing three of the trigonal-bipyramidal ( $\mathrm{Cu} 1, \mathrm{Cu} 2, \mathrm{Cu} 1$ ', and $\mathrm{Cu} 2$ '), trigonal (Cu3 and $\mathrm{Cu} 3$ '), and tetrahedral (Cu4 and $\mathrm{Cu} 4$ ') copper atoms. Charge consideration requires a formal $\mathrm{Cu}_{4}^{\mathrm{I}} \mathrm{Cu}_{4}^{\mathrm{II}}$ description of this core and thus we can assign the $\mathrm{Cu} 1$ and $\mathrm{Cu} 2$ (Cu1' and $\mathrm{Cu} 2$ ') atoms to copper(II) oxidation state and the $\mathrm{Cu} 3$ and $\mathrm{Cu} 4$ (Cu3' and $\mathrm{Cu} 4$ ') atoms to copper(I) oxidation state, respectively. The $\mathrm{Cu}^{\mathrm{II}}-\mathrm{Cu}^{\mathrm{II}}$ separations, the $\mathrm{Cu} 1$ ' $-\mathrm{Cu} 2$ and $\mathrm{Cu} 1-\mathrm{Cu} 2$ distances, are 3.703(3) and 5.708(3) 
$\AA$, respectively, forming a rectangurar array of the four copper(II) ions in the octanuclear core. $\mathrm{The}^{\mathrm{Cu}}-\mathrm{Cu}^{\mathrm{I}}(\mathrm{Cu} 3-\mathrm{Cu} 4)$ distance is 4.016(3) $\AA$. As for the $\mathrm{Cu}^{\mathrm{I}}-\mathrm{Cu}^{\mathrm{II}}$ separations, the $\mathrm{Cu} 2-\mathrm{Cu} 3, \mathrm{Cu} 2-\mathrm{Cu} 4, \mathrm{Cu} 1-\mathrm{Cu} 4$, and $\mathrm{Cu} 1$ '- $\mathrm{Cu} 4$ distances are 3.184(3), 3.968(3), 4.485(3), and 3.961(3) $\AA$, respectively. It is to be noted that the $\mathrm{Cu}$-S bond distances [2.273(6)$2.296(6) \AA]$ are comparable to the $\mathrm{Cu}^{\mathrm{II}}-\mathrm{S}$ bond lengths $[2.296(6), 2.298(6) \AA]$. Such a small difference is also found in 1 and both the $\mathrm{Cu}^{\mathrm{I}}-\mathrm{S}$ and $\mathrm{Cu}^{\mathrm{II}}-\mathrm{S}$ distances are comparable to the values found in thiolato-bridged mixed-valent $\mathrm{Cu}^{\mathrm{I}} \mathrm{Cu}^{\mathrm{II}}$ complexes [12-14].

The diffuse reflectance spectra of 2 (Fig. 4) contains broad features at 266, 330sh, 425, 554, 628, $736 \mathrm{~nm}$.

Table 2

Selected bond distances $(\AA)$ and angles $\left({ }^{\circ}\right)$, with esds in parentheses for $\left[\mathrm{Cu}_{4}^{\mathrm{I}} \mathrm{Cu}_{4}^{\mathrm{II}}(\mathrm{peampt}){ }_{4} \mathrm{Cl}_{8}\right] \cdot 2 \mathrm{H}_{2} \mathrm{O}$

\begin{tabular}{|c|c|c|c|}
\hline 2 & & & \\
\hline $\mathrm{Cu}(1)-\mathrm{N}(12)$ & $2.008(18)$ & $\mathrm{Cu}(1)-\mathrm{N}(11)$ & $2.082(19)$ \\
\hline $\mathrm{Cu}(1)-\mathrm{S}(1)$ & $2.296(6)$ & $\mathrm{Cu}(2)-\mathrm{N}(22)$ & $1.993(19)$ \\
\hline $\mathrm{Cu}(2)-\mathrm{N}(21)$ & $2.031(17)$ & $\mathrm{Cu}(2)-\mathrm{S}(2)$ & $2.298(6)$ \\
\hline $\mathrm{Cu}(3)-\mathrm{S}(1)$ & $2.273(6)$ & $\mathrm{Cu}(3)-\mathrm{S}(2)$ & $2.279(7)$ \\
\hline $\mathrm{Cu}(4)-\mathrm{Cl}(4)$ & $2.268(7)$ & $\mathrm{Cu}(4)-\mathrm{S}(1)^{\prime}$ & $2.292(6)$ \\
\hline $\mathrm{Cu}(4)-\mathrm{S}(2)$ & $2.296(6)$ & $\mathrm{Cu}(4)-\mathrm{Cl}(1)$ & $2.683(7)$ \\
\hline $\mathrm{Cu}(1)-\mathrm{Cl}(1)^{\prime}$ & $2.338(6)$ & $\mathrm{Cu}(1)-\mathrm{Cl}(2){ }^{\prime}$ & $2.740(7)$ \\
\hline $\mathrm{Cu}(2)-\mathrm{Cl}(1)$ & $2.351(6)$ & $\mathrm{Cu}(2)-\mathrm{Cl}(2)$ & $2.767(8)$ \\
\hline $\mathrm{Cu}(3)-\mathrm{Cl}(3)$ & $2.225(7)$ & & \\
\hline $\mathrm{N}(12)-\mathrm{Cu}(1)-\mathrm{N}(11)$ & $93.6(8)$ & $\mathrm{N}(12)-\mathrm{Cu}(1)-\mathrm{S}(1)$ & $88.5(5)$ \\
\hline $\mathrm{N}(11)-\mathrm{Cu}(1)-\mathrm{S}(1)$ & $142.0(6)$ & $\mathrm{N}(12)-\mathrm{Cu}(1)-\mathrm{Cl}(1)^{\prime}$ & $171.1(5)$ \\
\hline $\mathrm{N}(11)-\mathrm{Cu}(1)-\mathrm{Cl}(1)^{\prime}$ & $91.5(6)$ & $\mathrm{S}(1)-\mathrm{Cu}(1)-\mathrm{Cl}(1)^{\prime}$ & $92.0(2)$ \\
\hline $\mathrm{N}(12)-\mathrm{Cu}(1)-\mathrm{Cl}(2)^{\prime}$ & $87.3(5)$ & $\mathrm{N}(11)-\mathrm{Cu}(1)-\mathrm{Cl}(2)^{\prime}$ & $110.5(6)$ \\
\hline $\mathrm{S}(1)-\mathrm{Cu}(1)-\mathrm{Cl}(2)$ & $107.6(2)$ & $\mathrm{Cl}(1)^{\prime}-\mathrm{Cu}(1)-\mathrm{Cl}(2)^{\prime}$ & $84.2(2)$ \\
\hline $\mathrm{N}(22)-\mathrm{Cu}(2)-\mathrm{N}(21)$ & $94.5(8)$ & $\mathrm{N}(22)-\mathrm{Cu}(2)-\mathrm{S}(2)$ & $87.2(5)$ \\
\hline $\mathrm{N}(21)-\mathrm{Cu}(2)-\mathrm{S}(2)$ & $143.8(6)$ & $\mathrm{N}(22)-\mathrm{Cu}(2)-\mathrm{Cl}(1)$ & $169.6(5)$ \\
\hline $\mathrm{N}(21)-\mathrm{Cu}(2)-\mathrm{Cl}(1)$ & $92.4(6)$ & $\mathrm{S}(2)-\mathrm{Cu}(2)-\mathrm{Cl}(1)$ & $91.9(2)$ \\
\hline $\mathrm{N}(22)-\mathrm{Cu}(2)-\mathrm{Cl}(2)$ & $87.1(5)$ & $\mathrm{N}(21)-\mathrm{Cu}(2)-\mathrm{Cl}(2)$ & $108.9(6)$ \\
\hline $\mathrm{S}(2)-\mathrm{Cu}(2)-\mathrm{Cl}(2)$ & $107.3(2)$ & $\mathrm{Cl}(1)-\mathrm{Cu}(2)-\mathrm{Cl}(2)$ & $83.3(2)$ \\
\hline $\mathrm{Cl}(3)-\mathrm{Cu}(3)-\mathrm{S}(1)$ & $122.7(3)$ & $\mathrm{Cl}(3)-\mathrm{Cu}(3)-\mathrm{S}(2)$ & $121.3(3)$ \\
\hline $\mathrm{S}(1)-\mathrm{Cu}(3)-\mathrm{S}(2)$ & $116.0(2)$ & $\mathrm{Cl}(4)-\mathrm{Cu}(4)-\mathrm{S}(1){ }^{\prime}$ & $119.8(3)$ \\
\hline $\mathrm{Cl}(4)-\mathrm{Cu}(4)-\mathrm{S}(2)$ & $121.0(3)$ & $\mathrm{S}(1)-\mathrm{Cu}(4)-\mathrm{S}(2)$ & $115.8(2)$ \\
\hline $\mathrm{Cl}(4)-\mathrm{Cu}(4)-\mathrm{Cl}(1)$ & $100.4(3)$ & $\mathrm{S}(1)^{\prime}-\mathrm{Cu}(4)-\mathrm{Cl}(1)^{\prime}$ & $93.9(2)$ \\
\hline $\mathrm{S}(2)-\mathrm{Cu}(4)-\mathrm{Cl}(1)$ & $93.7(2)$ & $\mathrm{Cu}(3)-\mathrm{S}(1)-\mathrm{Cu}(4){ }^{\prime}$ & $125.0(3)$ \\
\hline $\mathrm{Cu}(3)-\mathrm{S}(1)-\mathrm{Cu}(1)$ & $84.9(2)$ & $\mathrm{Cu}(4)^{\prime}-\mathrm{S}(1)-\mathrm{Cu}(1)$ & $119.4(2)$ \\
\hline $\mathrm{Cu}(3)-\mathrm{S}(2)-\mathrm{Cu}(4)$ & $122.8(3)$ & $\mathrm{Cu}(3)-\mathrm{S}(2)-\mathrm{Cu}(2)$ & $88.2(2)$ \\
\hline $\mathrm{Cu}(4)-\mathrm{S}(2)-\mathrm{Cu}(2)$ & $119.5(3)$ & $\mathrm{Cu}(1)-\mathrm{Cl}(1)^{\prime}-\mathrm{Cu}(2)^{\prime}$ & $104.3(2)$ \\
\hline $\mathrm{Cu}(1)-\mathrm{Cl}(1)^{\prime}-\mathrm{Cu}(4)$ & $126.4(2)$ & $\mathrm{Cu}(2)-\mathrm{Cl}(1)-\mathrm{Cu}(4)$ & $125.9(2)$ \\
\hline $\mathrm{Cu}(1)^{\prime}-\mathrm{Cl}(2)-\mathrm{Cu}(2)$ & $84.5(2)$ & & \\
\hline
\end{tabular}

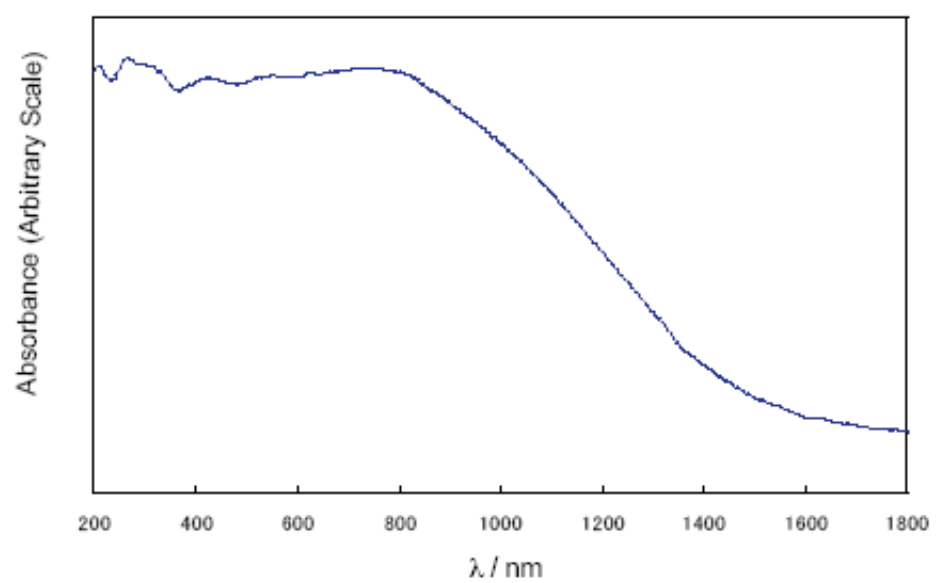

Fig. 4. Diffuse reflectance spectra of $\left[\mathrm{Cu}_{4}^{\mathrm{I}} \mathrm{Cu}_{4}{ }_{4}(\text { peampt })_{4} \mathrm{Cl}_{8}\right] \cdot 2 \mathrm{H}_{2} \mathrm{O}(2)$. 
The former two absorption bands in the UV region can be attributed to chloro-to- $\mathrm{Cu}^{\mathrm{II}}$ and thiolato-to- $\mathrm{Cu}^{\mathrm{II}}$ charge transfer transitions, respectively [13]. The absorption bands in the visible region can be assigned to the d-d transitions of the $\mathrm{Cu}^{\mathrm{II}} \mathrm{N}_{2} \mathrm{SCl}_{2}$ chromophores. The mixed-valence state of 2 may be considered to be fully localized because of no observation of the IT band in the near IR region.

The magnetic moment of 2 is $2.98 \mu_{\mathrm{B}}$ at $300 \mathrm{~K}$ per $\left[\mathrm{Cu}_{4}^{\mathrm{I}} \mathrm{Cu}_{4}^{\mathrm{II}}(\mathrm{peampt})_{4} \mathrm{Cl}_{8}\right] \cdot 2 \mathrm{H}_{2} \mathrm{O}$ unit, which is lower than the spin-only value of $3.46 \mu_{\mathrm{B}}$. Temperature dependence of the magnetic susceptibilities and moments are shown in Fig. 5.

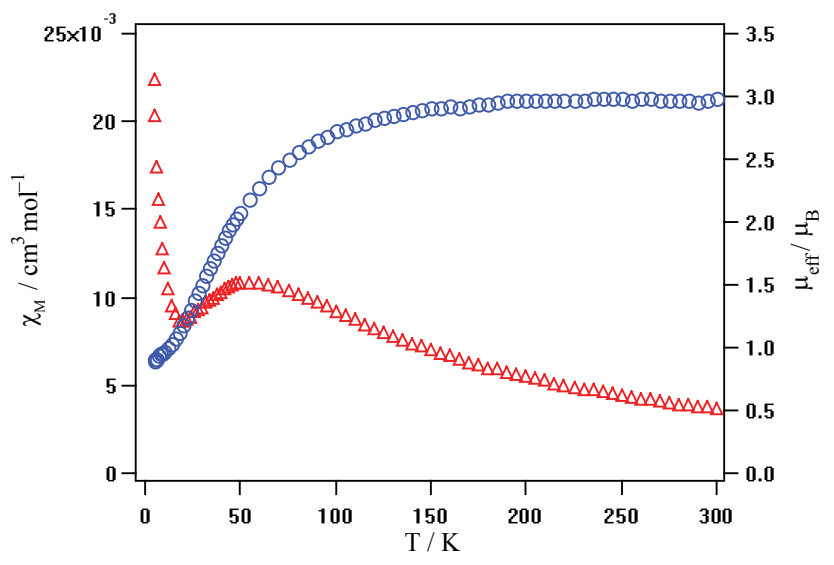

Fig. 5. Temperature dependence of magnetic susceptibilities and moments of $\left[\mathrm{Cu}_{4}^{\mathrm{I}} \mathrm{Cu}_{4}^{\mathrm{II}}(\mathrm{peampt})_{4} \mathrm{Cl}_{8}\right] \cdot 2 \mathrm{H}_{2} \mathrm{O}(2)$.

The magnetic moment is decreased with lowering the temperature. Thus, we can expect an antiferromagnetic interaction is operating between the four copper(II) ions. Although some attempts of fitting the magnetic data by using the van Vleck equation based on the Heisenberg model $H=-2\left[J_{1}\left(S_{1} \cdot S_{2}+S_{3} \cdot S_{4}\right)+J_{2}\left(S_{1} \bullet S_{4}+S_{2} \cdot S_{3}\right)\right]$ considering the location of the four copper(II) ions [15], where $J_{1}$ and $J_{2}$ correspond to the magnetic interactions between the Cu1' and $\mathrm{Cu} 2\left(\mathrm{Cu} 1\right.$ and $\left.\mathrm{Cu} 2{ }^{\prime}\right)$ and the $\mathrm{Cu} 1$ and $\mathrm{Cu} 2\left(\mathrm{Cu} 1^{\prime}\right.$ and $\mathrm{Cu} 2$ ') ions, respectively, were made, reasonable magnetic parameters were not obtained because of the serious influence of the paramagnetic impurity at low temperature.

\section{CONCLUSIONS}

N,N,S-donor tridentate thiol, 1-[(2-pyridylethyl)amino]methylpropane-2-thiol (Hpeampt), was synthesized and proved to be worked to prepare a thiolato-bridged mixed valent complex. Analytical data, IR and UV-vis spectroscopic data, and magnetic susceptibility data as well as X-ray crystal structure support a localized mixed-valent $\mathrm{Cu}^{\mathrm{I}} \mathrm{Cu}^{\mathrm{II}}$ state of the thiolato-bridged complex with peampt ${ }^{-}$. The formation of the octanuclear cluster may be achieved by the protection from oxidation reaction and solvent attack through the steric hindrance of the $\beta$-methyl groups of the present thiolic ligand.

\section{EXPERIMENTAL}

Synthesis: Syntheses of tholic ligand and metal complex were carried out by using standard Schlenk techniques under argon. The thiolic ligand Hpeampt was synthesized as follows. A toluene solution ( $70 \mathrm{~mL})$ of isobutylene sulfide $(11.8 \mathrm{~g}, 0.13 \mathrm{~mol})$ was added dropwise to a toluene solution $(50 \mathrm{~mL})$ containing 2-(2-aminoethyl)pyridine. The solution was refluxed for $24 \mathrm{~h}$. Then, the solvent was removed by distillation and the product was fractionally distilled at reduced pressure. Bp. $138-140^{\circ} \mathrm{C} / 5 \mathrm{mmHg}$.

$\left[\mathrm{Cu}_{4}^{\mathrm{I}} \mathrm{Cu}_{4}{ }_{4}^{\mathrm{II}}(\text { peampt })_{4} \mathrm{Cl}_{8}\right] \cdot 2 \mathrm{H}_{2} \mathrm{O}(2)$. To a solution of Hpeampt (42 mg, $\left.0.2 \mathrm{mmol}\right)$ in methanol $(5 \mathrm{~mL})$ was added a solution $(5 \mathrm{~mL})$ of copper(II) chloride dihydrate $(17 \mathrm{mg}, 0.1 \mathrm{mmol})$ in methanol $(5 \mathrm{~mL})$. The reaction mixture was stirred at $80^{\circ} \mathrm{C}$ for $10 \mathrm{~min}$. The resulting dark brown solution was allowed to stand several days at room temperature. The black plates deposited were collected by filtration. Found: $\mathrm{C}, 32.15 ; \mathrm{H}, 4.39 ; \mathrm{N}, 6.33 \%$. Calcd for $\mathrm{C}_{44} \mathrm{H}_{72} \mathrm{Cl}_{8} \mathrm{Cu}_{8} \mathrm{~N}_{8} \mathrm{O}_{2} \mathrm{~S}_{4}$, $\mathrm{C}, 31.73 ; \mathrm{H}, 4.36 ; \mathrm{N}, 6.73 \%$. IR $\left(\mathrm{KBr}, \mathrm{cm}^{-1}\right): v_{\text {as }}(\mathrm{OH}) 3449, v_{\mathrm{s}}(\mathrm{NH}) 3254,3205, v\left(\mathrm{CH}_{3}\right) 2960, v\left(\mathrm{CH}_{2}\right) 2860$. Diffuse reflectance spectra $\left(\lambda_{\max } / \mathrm{nm}\right): 266,330,425 \mathrm{sh}, 554,628,736$. Magnetic moment $\left(\mu_{\mathrm{eff}} / \mu_{\mathrm{B}}(T / \mathrm{K})\right): 2.98(300)$.

Measurements: Elemental analyses for carbon, hydrogen, and nitrogen were done using a Thermo-Finnigan FLASH EA1112 analyzer. Infrared spectra were measured with a JASCO MFT-2000 FT-IR Spectrometer in the 4000$600 \mathrm{~cm}^{-1}$ region. Electronic spectra were measured with a Shimadzu UV-vis-NIR Recording Spectrophotometer (Model UV-3100). Variable-temperature magnetic susceptibilities were measured with a Quantum Design MPMS-5S SQUID susceptometer operating at a magnetic field of $0.5 \mathrm{~T}$ over a range of $4.5-300 \mathrm{~K}$. The susceptibilities were corrected for the diamagnetism of the constituent atoms using Pascal's constants. The effective magnetic moments were calculated from the equation $\mu_{\text {eff }}=2.828 \sqrt{ } \chi_{\mathrm{M}} T$, where $\chi_{\mathrm{M}}$ is the molar magnetic susceptibility. 
X-Ray Crystallography: A preliminary examination was made and data were collected on a Bruker CCD X-ray diffractometer (SMART APEX) using graphite-monochromated Mo-Kọ radiation at $20 \pm 2{ }^{\circ} \mathrm{C}$. The structure was solved by direct methods and refined by full-matrix least-squares. All non-hydrogen atoms were refined with anisotropic thermal parameters. The hydrogen atoms were inserted at their calculated positions and fixed at their positions. All of the calculations were carried out on a Pentium III Windows NT computer utilizing the SHELXTL software package. CCDC 632152 (2) contains supplementary crystallographic data for this paper. These data can be obtained free of charge at www.ccdc.cam.ac.uk/conts/retrieving.html [or from the Cambridge Crystallographic Data Centre, 12 Union Road, Cambridge CB12 1EZ, UK; fax: (internet.) +44-1223/336-033; E-mail: deposit@ccdc.cam.ac.uk].

\section{ACKNOWLEDGEMENTS}

The present work was partially supported by the "Open research Center" Project for private Universities: matching fund subsidy and Grants-in-Aid for Scientific research Nos. 16550062 and 19550074 from the Ministry of Education, Culture, Sports, Science and Technology (Japan).

\section{REFERENCES}

[1] Fleischer, H. Coord. Chem. Rev. 2005, 249, 799-827.

[2] Andrew, C. R.; Sanders-Loehr, J. Acc. Chem. Res. 1996, 29, 365-372.

[3] Mandal, S.; Das, G.; Singh, R.; Shukla, R.; Bharadwaj, P. K. Coord. Chem. Rev. 1997, 160, 191-235.

[4] Handa, M.; Mikuriya, M; Zhuang, J.-Z.; Okawa, H.; Kida, S. Bull. Chem. Soc. Jpn. 1988, 61, 3883-3887.

[5] Kawahashi, T.; Mikuriya, M.; Nukada, R.; Lim, J.-W. Bull. Chem. Soc. Jpn. 2001, 74, 323-329.

[6] Mikuriya, M.; Xiao, J.; Ikemi, S.; Kawahashi, T.; Tsutsumi, H. Bull. Chem. Soc. Jpn. 1998, 71, $2161-2168$.

[7] Mikuriya, M.; Adachi, F.; Iwasawa, H.; Handa, M.; Koikawa, M.; Okawa, H. Bull. Chem. Soc. Jpn. 1994, 67, 3263-3270.

[8] Mikuriya, M.; Kotera, T.; Adachi, F.; Handa, M.; Koikawa, M.; Okawa, H. Bull. Chem. Soc. Jpn. 1995, 68, 574-580.

[9] Mikuriya, M.; Xiao, J.; Ikemi, S.; Kawahashi, T.; Tsutsumi, H.; Nakasone, A.; Lim, J.-W. Inorg. Chim. Acta 2001, 312, 183-187.

[10] Kotera, T.; Fujita, A.; Mikuriya, M.; Tsutsumi, H.; Handa, M. Inorg. Chem. Commun. 2003, 6, $322-324$.

[11] Mikuriya, M.; Tsutsumi, H.; Nukada, R.; Handa, M.; Sayama, Y. Bull. Chem. Soc. Jpn. 1996, 69, $3489-3498$.

[12] Kotera, T.; Fujita, A.; Mikuriya, M.; Handa, M. Materi. Sci. 2003, 21, 171-179.

[13] Kotera, T.; Mikuriya, M. Chem. Lett. 2002, 654-655.

[14] Dunaj-Jurco, M.; Ondrejovic, G.; Melnik, M. Coord. Chem. Rev. 1988, 83, 1-28.

[15] Alzuet, G.; Real, J. A.; Borras, J.; Santiago-Garcia, R.; Garcia-Granda, S. Inorg. Chem. 2001, 40, $2420-2423$. 